\title{
Behaviour of pharmaceuticals and endocrine disrupting chemicals in simplified sewage treatment systems
}

\author{
Emanuel M.F. Brandt ${ }^{a}$, Fernanda B. de Queiroz ${ }^{\text {b }}$, Robson J.C.F. Afonso ${ }^{\mathrm{b}}$, Sérgio F. Aquino ${ }^{\mathrm{b}}$, \\ Carlos A.L. Chernicharo ${ }^{\mathrm{a}, *}$ \\ ${ }^{a}$ Department of Sanitary and Environmental Engineering (Departamento de Engenharia Sanitária e Ambiental - DESA), Faculty of Engineering \\ (Escola de Engenharia), Federal University of Minas Gerais (Universidade Federal de Minas Gerais), Av. Antônio Carlos, 6627, BL 1 - sala 4623, \\ 31270-901 Belo Horizonte, MG, Brazil \\ ${ }^{\mathrm{b}}$ Department of Chemistry (Departamento de Química - DEQUI), Federal University of Ouro Preto (Universidade Federal de Ouro Preto), Campus \\ Universitário Morro do Cruzeiro, 35400-000 Ouro Preto, MG, Brazil
}

\section{A R T I C L E I N F O}

\section{Article history:}

Received 10 May 2012

Received in revised form

5 June 2013

Accepted 11 June 2013

Available online 11 July 2013

\section{Keywords:}

Micropollutant

Oestrogen

Antibiotic

UASB/submerged bed system

UASB/polishing pond system

UASB/trickling filter system

\begin{abstract}
A B S T R A C T
This work assessed the behaviour of nine pharmaceuticals and/or endocrine disrupting chemicals (EDCs) in demo-scale upflow anaerobic sludge blanket reactors (UASB reactors) coupled to distinct simplified post-treatment units (submerged bed, polishing ponds, and trickling filters) fed on raw sewage taken from a municipality in Brazil. The dissolved concentration of the studied micropollutants in the raw and treated sewage was obtained using solid phase extraction (SPE) followed by analysis in a liquid chromatography system coupled to a hybrid high resolution mass spectrometer consisting of an ion-trap and time of flight (LC-MS-IT-TOF). The UASB reactors demonstrated that they were not appropriate for efficiently removing the assessed compounds from the sewage. Furthermore, this study demonstrated that the hydraulic retention time (HRT) was an important parameter for the removal of the hydrophilic and less biodegradable compounds, such as trimethoprim and sulfamethoxazole. The post-treatment units substantially increased the removal of most target micropollutants present in the anaerobic effluents, with a greater removal of micropollutants in simplified systems that require a large construction area, such as the submerged bed and polishing ponds, probably because of the higher HRT employed. Alternatively, compact post-treatment systems, such as trickling filters, tended to be less effective at removing most of the micropollutants studied, and the type of packing proved to be crucial for determining the fate of such compounds using trickling filters.
\end{abstract}

(c) 2013 Elsevier Ltd. All rights reserved.

\section{Introduction}

The environmental monitoring of so-called emerging pollutants has gained great interest from the scientific community since the 1970s and 1980s (Aherne et al., 1985; Hignite and Azarnoff, 1977), especially because of their potential effects, such as aquatic toxicity, genotoxicity, and endocrine disruption in wildlife, along with the selection of resistant pathogenic bacteria, among others (HallingSørensen et al., 1998; Kim and Aga, 2007; Kümmerer, 2010). Several classes of drugs are included in this group of contaminants (e.g., analgesics, antibiotics, lipid regulators, anti-inflammatories, synthetic hormones, etc.), as well as substances used in cleaning and personal care products, compounds used in the production of resins and plastics, pesticides, and natural hormones and their by-

\footnotetext{
* Corresponding author. Tel.: +55 313409 1020; fax: +55 3134091879

E-mail address: calemos@desa.ufmg.br (C.A.L. Chernicharo).
}

products. The micropollutant term also applies generally to contaminants that occur in the environment at concentrations on the order of micrograms per litre or lower.

From all the micropollutants that might be present in water and wastewater, special attention has been given to those classified as endocrine disrupting chemicals (EDCs). Such compounds can affect the endocrine system of several organisms (including humans), causing anomalies in reproductive systems, feminisation, decreased quality of semen, and other adverse effects (Carlsen et al., 1992; Guillette et al., 1996; Jobling et al., 1998; Kashiwada et al., 2002; Vandenberg et al., 2007; WHO, 2002).

Many pharmaceuticals and EDCs reach sewage systems through bathing, cleaning, laundry, the excreta of individuals (in the case of oral medicines and natural hormones), and the disposal of unused or expired pharmaceuticals in the toilet. Wastewater treatment plants (WWTPs) are designed to reduce the load of organic pollutants and, in some cases, pathogens and nutrients. However, WWTPs are not designed to specifically remove pharmaceuticals 
and EDCs; therefore, any removal of these micropollutants that may occur is incidental to the wastewater treatment processes (USEPA, 2009).

Currently, there are numerous studies addressing the occurrence of these compounds in sewage, the effluent from WWTPs, surface water, and, less frequently, in tap waters (Jelic et al., 2011; Kasprzyk-Hordern et al., 2009; Kim et al., 2007; Miège et al., 2008; Sodré et al., 2010; Ternes, 1998). Despite a significant increase in research on the subject in the last decades, the occurrence of several micropollutants in environmental matrices has not been established for many countries, mainly due to the difficulties and costs associated with the chemical analyses (Virkutyte et al., 2010). Brazil fits into this context, with only a handful of studies reporting on the occurrence of a few compounds (Froehner et al., 2011; Moreira et al., 2009, 2011; Sodré et al., 2010; Stumpf et al., 1999; Ternes et al., 1999).

There are several studies worldwide assessing the behaviour of micropollutants in WWTPs; however, the majority of them refer to activated sludge systems and membrane bioreactors, which are systems most commonly used in European countries, the USA, Canada, South Korea, China, and Japan (Clara et al., 2005a; Gulkowska et al., 2008; Kim et al., 2007; Li and Zhang, 2010; Miège et al., 2008; Sipma et al., 2009; Ternes et al., 1999). A literature review on the topic shows that little is known about the fate of these contaminants in WWTPs consisting of compact anaerobic reactors (e.g., upflow anaerobic sludge blanket reactors - UASB or expanded granular sludge bed reactors - EGSBs) followed by simplified post-treatment units (e.g., ponds, wetlands, trickling filters).
Because of the great applicability of UASB reactors combined with aerobic post-treatment units in developing countries with hot climates such as Brazil (Chernicharo, 2006), it is important to evaluate the efficiency of these systems on the removal of micropollutants. Therefore, the main objective of this paper is to assess the behaviour of nine pharmaceuticals and/or EDCs in demo-scale UASB reactors coupled to distinct simplified post-treatment units (submerged beds, polishing ponds, and trickling filters).

\section{Materials and methods}

\subsection{Area of study}

The experiments were carried out in demo-scale treatment systems (Fig. 1) comprised of three UASB reactors followed by the following simplified post-treatments: (1) a submerged bed filled with blast furnace slag and operated at subsurface flow; (2) two trickling filters packed with different bed medias (plastic and sponge based) as described by Almeida et al. (2011); (3) three polishing ponds operated in series with a coarse filter stone leased at the end of the third pond.

The systems were installed at the Centre for Research and Training in Sanitation (CePTS) UFMG/COPASA, located at the Arrudas WWTP (design flow rate of $4.5 \mathrm{~m}^{3} \mathrm{~s}^{-1}$ ) in Belo Horizonte, Brazil (coordinates $19^{\circ} 53^{\prime} 42^{\prime \prime} \mathrm{S}$ and $43^{\circ} 52^{\prime} 42^{\prime \prime} \mathrm{W}$, altitude $800 \mathrm{~m}$ ). The reactors were fed on a parcel of the wastewater taken from a chamber upstream of the primary clarifiers of the full-scale plant after being submitted to preliminary treatment for solids and grit removal, thereby representing a typical urban wastewater. The

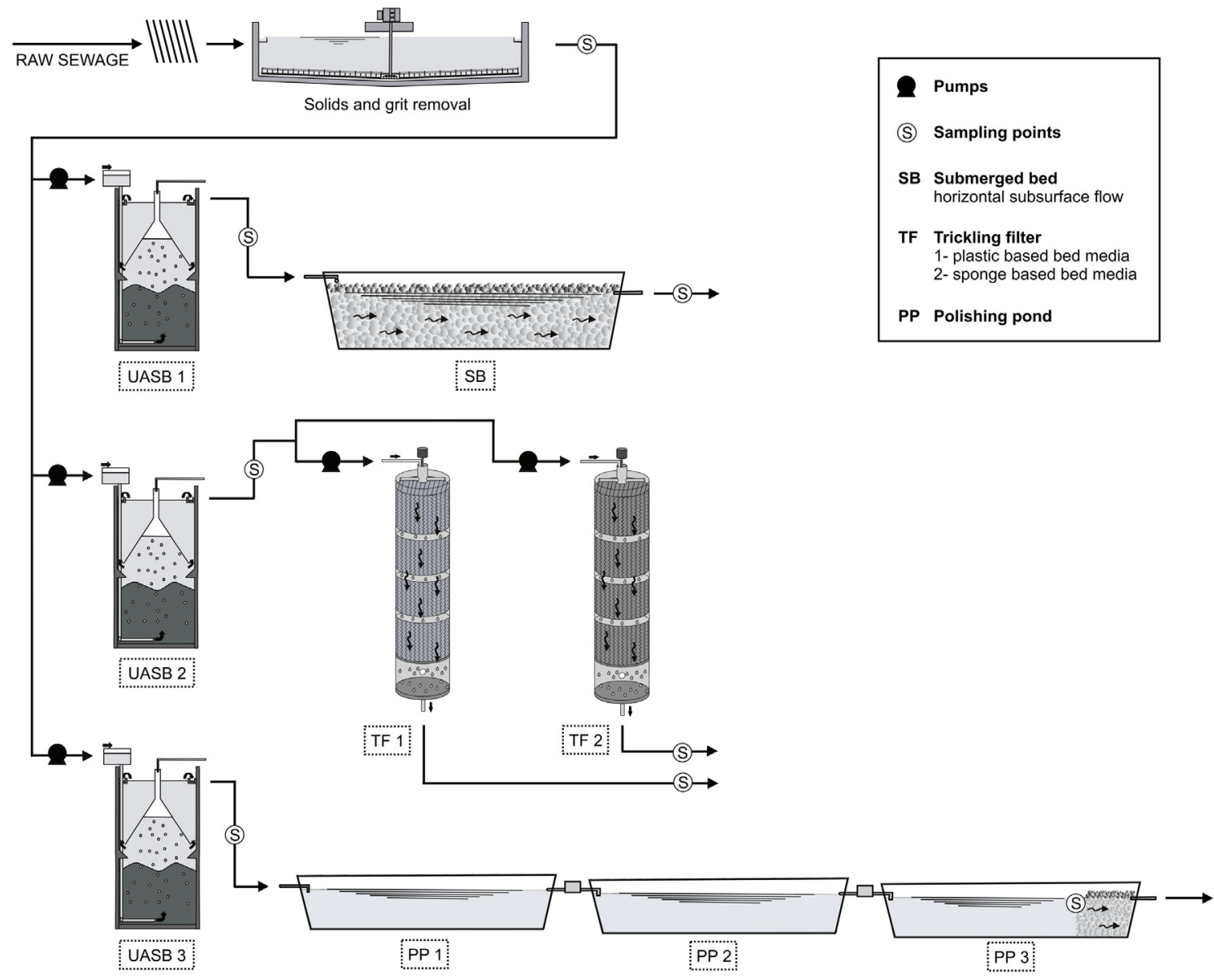

Fig. 1. Flow sheet and sampling points of the demo-scale treatment systems. 
Table 1

Main characteristics and operational conditions of the demo-scale UASB reactors studied.

\begin{tabular}{|c|c|c|c|}
\hline $\begin{array}{l}\text { Characteristics and } \\
\text { parameters }\end{array}$ & UASB 1 & UASB 2 & UASB 3 \\
\hline Building material & Stainless steel & Stainless steel & $\begin{array}{l}\text { Iron armoured } \\
\text { cement }\end{array}$ \\
\hline Cross section (m) & $1.2 \times 1.2$ & $1.4 \times 2.5$ & Diameter $=2.0$ \\
\hline Useful height (m) & 5.0 & 4.8 & 4.5 \\
\hline Useful volume $\left(\mathrm{m}^{3}\right)$ & 7.2 & 16.8 & 14.1 \\
\hline Average HRT \pm SD $(h)$ & $5.4 \pm 0.3$ & $8.7 \pm 1.0$ & $11.0 \pm 0.8$ \\
\hline $\begin{array}{l}\text { Average upflow } \\
\quad \text { velocity } \pm S D\left(\mathrm{~m} \mathrm{~h}^{-1}\right)\end{array}$ & $0.93 \pm 0.05$ & $0.56 \pm 0.06$ & $0.41 \pm 0.03$ \\
\hline $\begin{array}{l}\text { Average OLR } \pm \text { SD } \\
\quad\left(\operatorname{kgCOD} \cdot \mathrm{m}^{-3} \cdot \mathrm{d}^{-1}\right)\end{array}$ & $2.4 \pm 0.6$ & $1.5 \pm 0.3$ & $1.1 \pm 0.3$ \\
\hline
\end{tabular}

SD - standard deviation; HRT - hydraulic retention time; OLR - organic loading rate; COD - chemical oxygen demand.

main characteristics and operational conditions of the treatment units are presented in Table 1 and Table 2; the main physicalchemical characteristics of the raw sewage and the 24-hour accumulated rainfall during the micropollutant sampling campaign are depicted in Table 3. From this table, it can be observed that the municipality had been through a long period of drought during the sampling campaign because there were no observed rainfalls, confirming that there was no dilution of the sewage with rainwater.

\subsection{Analytical methods}

The choice of the target compounds for this study was based on their reported threat and occurrence, as well as the availability and technical feasibility of the analytical method used. Thus, this study evaluated the following compounds: $17 \beta$-estradiol (E2), $17 \alpha$-ethinylestradiol (EE2), nonylphenol (NP), bisphenol A (BPA), sulfamethoxazole (SMX), trimethoprim (TRI), bezafibrate (BZF), diclofenac (DCF), and miconazole (MCZ).

\subsubsection{Sample preparation and collection}

All target compounds were concentrated using solid phase extraction and analysed by liquid chromatography with tandem mass spectrometry (LC-MS). Initially, 12 samples composed of raw and treated sewage (effluents from the systems) were collected during a sampling campaign carried out from June to August, 2010, as shown in Fig. 1. For this purpose, $20 \mathrm{~L}$ of sewage was sampled over a 24-h period at each sampling point using a sampling collector (except for the submerged bed and polishing pond effluents, which were grab-sampled between 8:00 and 10:00 a.m.). Then, $300 \mathrm{~mL}$ of the cooled samples was taken for filtration $(0.7-\mu \mathrm{m}$ glassfibre filter) and further preparation.
Table 3

Physical-chemical characteristics of the raw sewage and accumulated rainfall during the sampling campaign.

\begin{tabular}{llcrrr}
\hline Parameter & $\mathrm{N}$ & Mean $\pm \mathrm{SD}$ & Median & Min & Max \\
\hline Total COD $\left(\mathrm{mg} \mathrm{L}^{-1}\right)$ & 21 & $514 \pm 130$ & 492 & 292 & 770 \\
Total BOD $\left(\mathrm{mg} \mathrm{L}^{-1}\right)$ & 13 & $270 \pm 71$ & 265 & 203 & 490 \\
Dissolved OC $\left(\mathrm{mg} \mathrm{L}^{-1}\right)$ & 21 & $55 \pm 14$ & 58 & 27 & 88 \\
Total SS $\left(\mathrm{mg} \mathrm{L}^{-1}\right)$ & 21 & $348 \pm 182$ & 285 & 166 & 794 \\
Temperature $\left({ }^{\circ} \mathrm{C}\right)$ & 21 & $21.4 \pm 1.7$ & 21.7 & 16.0 & 23.2 \\
pH & 21 & $7.1 \pm 0.1$ & 7.1 & 6.9 & 7.4 \\
24-hraccumulated & 58 & $0.0 \pm 0.0$ & 0.0 & 0.0 & 0.0 \\
$\quad$ rainfall $(\mathrm{mm})$ & & & & & \\
\hline
\end{tabular}

SD - standard deviation; COD - chemical oxygen demand; BOD -biochemical oxygen demand; OC - organic carbon; SS - suspended solids.

\subsubsection{Solid phase extraction}

A solid phase extraction (SPE) based on the Method 1694 (USEPA, 2007) was used to concentrate the target contaminants prior to the chromatographic analysis. For this, two SPE cartridges (Strata SAX ${ }^{\circledR}-500 \mathrm{mg}$ and Strata $\mathrm{X}^{\circledR}-500 \mathrm{mg}$, both from Phenomenex) were used in a row to clean up the samples and concentrate the analytes. First, $100 \mathrm{~mL}$ of each filtered sample was passed through the Strata SAX (ion exchange) that had been previously conditioned with $10 \mathrm{~mL}$ of methanol and $10 \mathrm{~mL}$ of deionised (DI) water. The eluate recovered from this step was adjusted to $\mathrm{pH}$ $2.0(\mathrm{HCl} 0.1 \mathrm{M})$ before receiving $50 \mathrm{mg}$ of EDTA. After $2 \mathrm{~h}$, this eluate was then passed through the Strata X (hydrophilic/lipophilic) that had been conditioned with $10 \mathrm{~mL}$ of methanol, $10 \mathrm{~mL}$ of DI water and $6 \mathrm{~mL}$ of an $\mathrm{HCl}$ solution ( $\mathrm{pH} \mathrm{2}$ ). The flow rate used during all extraction procedures was $5 \mathrm{~mL} \cdot \mathrm{min}^{-1}$. The Strata SAX cartridges were then eluted with $10 \mathrm{~mL}$ of ethyl acetate, whereas the Strata X cartridges were eluted with $10 \mathrm{~mL}$ of methanol and $6 \mathrm{~mL}$ of a methanol:acetone mixture $(1: 1)$ to recover the analytes adsorbed onto them. The extracts were then dried at ambient temperature under a $\mathrm{N}_{2}$ flux, and the analytes were then re-dissolved in $0.4 \mathrm{~mL}$ of a 3:1 mixture of methanol:formic acid in $0.1 \% \mathrm{v} / \mathrm{v}$ methanol.

\subsubsection{Liquid chromatography-tandem mass spectrometry}

The organic extracts were kept in the freezer $\left(-15^{\circ} \mathrm{C}\right)$ until analysis, which was carried out in a Shimadzu liquid chromatography system coupled to a hybrid high resolution mass spectrometer consisting of an ion-trap and time of flight (LC-MS-IT-TOF). Two chromatographic columns (C18, $150 \mathrm{~mm} \times 2 \mathrm{~mm} \times 3 \mu \mathrm{m})$ were assembled in a row, resulting in a total chromatographic time of $35 \mathrm{~min}$. A flow rate of $0.2 \mathrm{~mL} \cdot \mathrm{min}^{-1}$ of gradient water and methanol (both prepared with $3 \mathrm{mM} \mathrm{NH}_{4} \mathrm{OH}$ ) was used as the mobile phase, and the volume of injection was $5 \mu \mathrm{L}$. Electron spray ionisation (ESI) was used for the analysis of all micropollutants, which were detected either in the positive (MCZ, SMX, and TRI) or negative (BZF, BPA, DCF, E2, EE2, and NP) mode.

Table 2

Main characteristics and operational conditions of the post-treatment units studied.

\begin{tabular}{|c|c|c|c|c|c|c|}
\hline \multirow[t]{2}{*}{ Characteristics and parameters } & \multirow[t]{2}{*}{ Submerged bed } & \multicolumn{2}{|c|}{ Trickling filters } & \multicolumn{3}{|c|}{ Polishing ponds } \\
\hline & & TF 1 & TF 2 & PP 1 & PP 2 & PP 3 \\
\hline Bed media & Blast furnace slag & Plastic based & Sponge based & 1 & 1 & 1 \\
\hline Cross section (m) & $3.0 \times 24.1$ & Diam. $=0.76$ & Diam. $=0.76$ & $5.25 \times 25.00$ & $5.25 \times 25.00$ & $5.25 \times 16.56^{\mathrm{a}}$ \\
\hline Useful height (m) & 0.3 & 4.0 & 4.0 & 0.75 & 0.70 & 0.50 \\
\hline Useful volume $\left(\mathrm{m}^{3}\right)$ & 9.0 & 1.81 & 1.81 & 64.7 & 60.3 & $42.0^{\mathrm{a}}$ \\
\hline Average $\mathrm{HRT} \pm \mathrm{SD}(\mathrm{h})$ & $29.2 \pm 2.9$ & $0.25^{\mathrm{b}}$ & $2.00^{\mathrm{b}}$ & $50.5 \pm 3.7$ & $47.1 \pm 3.4$ & $32.8 \pm 2.4^{\mathrm{a}}$ \\
\hline Average $\mathrm{HLR} \pm \mathrm{SD}\left(\mathrm{m}^{3} \mathrm{~m}^{-2} \cdot \mathrm{d}^{-1}\right)$ & $0.10 \pm 0.01$ & $10.2 \pm 0.4$ & $11.1 \pm 0.9$ & 1 & 1 & 1 \\
\hline Average OLR $\pm \mathrm{SD}\left(\mathrm{kgCOD} \cdot \mathrm{m}^{-3} \cdot \mathrm{d}^{-1}\right)$ & ND & $0.49 \pm 0.11$ & $0.53 \pm 0.10$ & ND & ND & ND \\
\hline
\end{tabular}

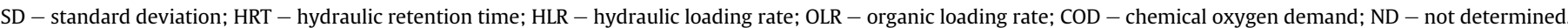

a data excluded from the coarse filter stone.

b HRT was estimated using a radioactive tracer method. 
Due to the possibility of matrix effects leading to the suppression of analytes during ionisation and therefore their underestimation, the chromatographic areas of all detected analytes were properly corrected. For this, each organic extract was analysed twice, both before and after a spike of a known concentration of the analytes investigated in this study. The LC-MS method was properly validated by Queiroz (2011), and data for the linearity, precision, limit of detection (LOD), limit of quantification (LOQ), and recovery index are depicted in Table 4. For NP, validation data were not presented because there might be a large number of NP isomers that were not separated and quantified in this study. The changes observed for NP were reported in terms of peak areas, since isomers separation and individual quantification were beyond the objectives of this study.

\section{Results and discussion}

\subsection{Micropollutant behaviour in UASB reactors}

Table 5 presents the dissolved concentration of micropollutants in the raw and treated sewage, and Fig. 2 shows the removal/ production efficiencies of the target compounds in the UASB reactors studied. The values in which both the influent and effluent were below the LOQ or LOD were not used to calculate the efficiencies reported in Fig. 2. In cases where only one data point (influent or effluent) was below the LOQ or LOD, the removal efficiency was calculated using half of the LOQ or LOD value. In addition, for NP, the changes observed were calculated in terms of the peak areas because there might be a large number of NP isomers that were not separated and quantified in this study. The range selected in the chromatogram was the same range presented for the standard peak from a mixture of NP isomers. The natural (E2) and synthetic (EE2) hormones, and the antifungal (MCZ) were hardly detected in the raw sewage; therefore, their behaviour is not described in Fig. 2 .

Fig. 2 illustrates that in most cases, there was production of NP and BPA in the anaerobic step, and Table 5 also shows that there seemed to be a higher concentration of NP in the effluent of UASB 3 $(\mathrm{HRT}=11.0 \mathrm{~h})$, followed by UASB $2(\mathrm{HRT}=8.7 \mathrm{~h})$ and then UASB 1 $($ HRT $=5.4 \mathrm{~h})$, indicating that NP formation was directly proportional to the HRT. However, this relationship was not statistically confirmed (nonparametric Kruskal-Wallis test, $\alpha=5 \%$ ) (Sprent and Smeeton, 2001), and Fig. 2 shows that the production of NP in the UASB reactors seemed to be very similar. The production of NP in biological treatments is commonly attributed to the degradation of precursor compounds, such as alkylphenolethoxylates (APEOs) present in cleaning formulations (Guenther et al., 2006).
The same behaviour occurred with BPA, where the accumulation in the UASB 3 was twice as high when compared to UASB 1 operated at the lowest HRT (confirmed by nonparametric Kruskal-Wallis test, $\alpha=5 \%$ )(Sprent and Smeeton, 2001). BPA is a widely used monomer for the production of polycarbonate plastic and epoxy resins, and it can also be used as an antioxidant in some plasticisers and as a polymerisation inhibitor in PVC plastic. Therefore, it is possible that some BPA might have leached out from the PVC pipes and the connections, thereby decreasing its removal in the anaerobic reactors studied.

Regarding the antibiotic SMX, Fig. 2 shows that only the UASB reactor operated at the highest HRT (UASB 3) was efficient in removing SMX from the liquid matrix because, in the other two UASB reactors, the concentrations of SMX in the liquid effluent matrices were roughly the same or even higher than those observed in the raw sewage (Table 5). The degradation of the acetylated sulphonamide $\mathrm{N}^{4}$-acetyl-sulfamethoxazole, an important human metabolite commonly present in municipal sewage, is considered to be responsible for the negative removal rates observed in biological systems (Plósz et al., 2010). Therefore, it seemed that an HRT of $11.0 \mathrm{~h}$ was sufficient to allow the degradation of both the acetylated sulphonamide metabolite and SMX.

As far as the antibiotic TRI is concerned, Fig. 2 shows that there seems to be a relationship between the HRT and removal efficiencies. However, this trend was not confirmed statistically (nonparametric Kruskal-Wallis test, $\alpha=5 \%$ ) (Sprent and Smeeton, 2001), which is possibly due to the large variability in the data and the small number of samples. The partial removal of TRI in the UASB reactors was probably due to its adsorption onto the anaerobic sludge because at the operational $\mathrm{pH}$ values (6.6-7.4), approximately half of the TRI molecules would be present in the protonated cationic form, thereby favouring its electrostatic interaction with the negative charges that normally prevail on the biomass surface (Suárez et al., 2008). Once adsorbed, the TRI could be anaerobically degraded or leave the system via the discharged sludge; this closely depends on the sludge management (sludge age) in the UASB reactors.

Fig. 2 also shows the changes in BZF and DCF concentrations upon the anaerobic treatment. The results indicate that the HRT had little effect on the behaviour of these pharmaceutical compounds. Although these compounds would tend to adsorb onto hydrophobic surfaces (such as UASB sludge), they would be deprotonated (with negative charge) at the UASB operational $\mathrm{pH}$ values. This would imply an electrostatic repulsion between BZF or DCF and the negatively charged sludge particles (Suárez et al., 2008), which could explain the low removal efficiencies observed. In addition, BZF and DCF are not easily biodegradable, especially in anaerobic environments where biodegradation rates are very low (Kujawa-Roeleveld et al., 2008).

Table 4

Validation parameters for the method used to analyse the selected micropollutants.

\begin{tabular}{|c|c|c|c|c|c|c|}
\hline \multirow[t]{2}{*}{ Compound } & \multirow[t]{2}{*}{$R^{2}$} & \multirow[t]{2}{*}{ Precision (\%) } & \multirow[t]{2}{*}{$\mathrm{LOD}^{\mathrm{b}}$} & \multirow[t]{2}{*}{$\mathrm{LOQ}^{\mathrm{b}}$} & \multicolumn{2}{|l|}{ Recovery index (\%) } \\
\hline & & & & & Strata SAX cartridge & Strata X cartridge \\
\hline Estradiol & 0.99 & 4.7 & 9.3 & 31.0 & $35.4 \pm 5.5$ & $8.0 \pm 6.5$ \\
\hline Ethinylestradiol & 0.99 & 4.8 & 12.4 & 41.3 & $23.2 \pm 9.5$ & $6.6 \pm 8.5$ \\
\hline Bisphenol A & 0.99 & 4.1 & $1.2-2.1$ & $4.0-7.1$ & $24.9 \pm 9.0$ & $37.6 \pm 5.5$ \\
\hline Sulfamethoxazole & 0.99 & 10.6 & $1.5-2.2$ & $5.1-7.4$ & $39.6 \pm 2.3^{c}$ & \\
\hline Trimethoprim & 0.99 & 6.4 & $1.0-1.4$ & $3.3-4.7$ & $29.2 \pm 1.9$ & $38.5 \pm 5.5$ \\
\hline Bezafibrate & 0.99 & 9.2 & $3.4-5.1$ & $11.3-17.1$ & $17.3 \pm 2.6$ & $38.3 \pm 6.1$ \\
\hline Diclofenac & 0.99 & 10.6 & $5.0-8.8$ & $16.5-29.3$ & $26.7 \pm 7.9$ & $19.9 \pm 6.8$ \\
\hline Miconazole & 0.97 & 4.2 & $2.6-4.1$ & $8.7-13.8$ & $33.6 \pm 2.0^{c}$ & \\
\hline
\end{tabular}

$R^{2}$ - linearity; LOD - limit of detection; LOQ - limit of quantification.

a average of three concentration levels $\left(10,50\right.$, and $\left.100 \mathrm{ng} . \mathrm{L}^{-1}\right), N=21$.

b calculated by the signal-to-noise ratio ( $\mathrm{S} / \mathrm{N}=3$ for LOD and $\mathrm{S} / \mathrm{N}=10$ for LOQ) considering a concentration factor of 250 , recovery and suppressive indexes observed for real samples.

c recoveries were obtained through a unique extract by eluting the two cartridges. 
Table 5

Concentrations of studied compounds in $\mathrm{ng} \mathrm{L}^{-1}$ at each sampling point (12 data values for each point).

\begin{tabular}{|c|c|c|c|c|c|c|c|c|c|}
\hline \multirow[t]{2}{*}{ Sampling points } & \multirow{2}{*}{$\begin{array}{l}\text { Descriptive } \\
\text { statistics }\end{array}$} & \multicolumn{8}{|l|}{ Compounds } \\
\hline & & E2 & EE2 & BPA & SMX & TRI & $\mathrm{BZF}$ & DCF & $\mathrm{MCZ}$ \\
\hline \multirow[t]{3}{*}{ Raw sewage } & Mean \pm SD & $<$ LOD & $<$ LOD & $175.3 \pm 63.9$ & $35.0 \pm 46.8$ & $64.5 \pm 28.1$ & $95.1 \pm 75.5$ & $105.2 \pm 81.3$ & $<\mathrm{LOQ}$ \\
\hline & Median & $<$ LOD & $<$ LOD & 164.6 & 13.0 & 61.5 & 94.4 & 99.9 & $<\mathrm{LOQ}$ \\
\hline & Min/Max & $<\mathrm{LOD} /<\mathrm{LOQ}$ & $<\mathrm{LOD} /<\mathrm{LOQ}$ & $55.7 / 308.8$ & $<$ LOD/150.8 & $23.2 / 113.7$ & $<$ LOD/249.2 & $<\mathrm{LOD} / 240.2$ & $<$ LOD/13.9 \\
\hline UASB 1 effluent & Mean \pm SD & $<$ LOD & $<$ LOD & $224.3 \pm 154.4$ & $27.2 \pm 45.7$ & $37.9 \pm 23.8$ & $70.2 \pm 66.2$ & $127.0 \pm 145.5$ & $30.4 \pm 79.0$ \\
\hline \multirow[t]{2}{*}{$\mathrm{HRT}=5.4 \mathrm{~h}$} & Median & $<$ LOD & $<$ LOD & 166.5 & 6.8 & 38.4 & 54.3 & 91.1 & $<$ LOQ \\
\hline & Min/Max & $<\mathrm{LOD} /<\mathrm{LOD}$ & $<\mathrm{LOD} /<\mathrm{LOD}$ & 71.5/520.6 & $<\mathrm{LOD} / 160.9$ & $4.3 / 87.6$ & $<$ LOD/207.8 & $<\mathrm{LOD} / 486.4$ & $<\mathrm{LOD} / 280.1$ \\
\hline UASB 2 effluent & Mean \pm SD & $<$ LOD & $<\mathrm{LOD}$ & $242.2 \pm 190.7$ & $41.9 \pm 46.4$ & $30.8 \pm 18.0$ & $75.7 \pm 78.5$ & $138.2 \pm 145.5$ & $<\mathrm{LOQ}$ \\
\hline \multirow[t]{2}{*}{$\mathrm{HRT}=8.7 \mathrm{~h}$} & Median & $<$ LOD & $<$ LOD & 175.5 & 29.2 & 32.4 & 44.1 & 97.6 & $<\mathrm{LOQ}$ \\
\hline & Min/Max & $<$ LOD $/<$ LOD & $<\mathrm{LOD} /<\mathrm{LOD}$ & $<\mathrm{LOQ} / 612.4$ & $<$ LOD/123.3 & $<\mathrm{LOQ} / 60.4$ & $<$ LOD/221.8 & $<\mathrm{LOD} / 469.2$ & $<$ LOD/17.6 \\
\hline UASB 3 effluent & Mean \pm SD & $<\mathrm{LOD}$ & $<$ LOD & $349.9 \pm 245.1$ & $16.5 \pm 20.3$ & $19.7 \pm 12.9$ & $68.5 \pm 79.7$ & $117.9 \pm 95.2$ & $<$ LOQ \\
\hline \multirow[t]{2}{*}{$\mathrm{HRT}=11.0 \mathrm{~h}$} & Median & $<$ LOD & $<$ LOD & 292.1 & $<$ LOD & 14.2 & 43.5 & 130.2 & $<\mathrm{LOQ}$ \\
\hline & Min/Max & $<\mathrm{LOD} /<\mathrm{LOD}$ & $<\mathrm{LOD} /<\mathrm{LOD}$ & $20.1 / 751.4$ & $<$ LOD/49.4 & $5.4 / 46.2$ & $<\mathrm{LOD} / 278.4$ & $<$ LOD/139.6 & $<\mathrm{LOQ} / 14.7$ \\
\hline \multirow{2}{*}{$\begin{array}{l}\text { Submerged bed } \\
\text { effluent }\end{array}$} & Mean \pm SD & $<$ LOD & $<$ LOD & $112.1 \pm 126.5$ & $<$ LOD & $4.8 \pm 10.7$ & $51.4 \pm 56.2$ & $130.0 \pm 135.3$ & $<$ LOD \\
\hline & Median & $<$ LOD & $<$ LOD & 77.6 & $<$ LOD & $<$ LOD & 25.8 & 112.6 & $<$ LOD \\
\hline $\begin{array}{l}\text { Horizontal } \\
\quad \text { subsurface flow }\end{array}$ & Min/Max & $<\mathrm{LOD} /<\mathrm{LOD}$ & $<\mathrm{LOD} /<\mathrm{LOD}$ & $<$ LOD/399.3 & $<\mathrm{LOD} /<\mathrm{LOD}$ & $<\mathrm{LOD} / 37.8$ & $<\mathrm{LOD} / 146.0$ & $<\mathrm{LOD} / 450.6$ & $<\mathrm{LOD} /<\mathrm{LOQ}$ \\
\hline Trickling filter & Mean \pm SD & $<$ LOD & $<$ LOD & $62.4 \pm 56.9$ & $27.3 \pm 43.7$ & $39.2 \pm 20.3$ & $99.7 \pm 67.6$ & $241.6 \pm 242.8$ & $<$ LOQ \\
\hline 1 effluent & Median & $<$ LOD & $<$ LOD & 41.0 & $<\mathrm{LOD}$ & 41.8 & 87.6 & 162.1 & $<$ LOQ \\
\hline Plasticbased media & Min/Max & $<\mathrm{LOD} /<\mathrm{LOD}$ & $<\mathrm{LOD} /<\mathrm{LOD}$ & $<\mathrm{LOQ} / 189.9$ & $<\mathrm{LOD} / 124.0$ & $5.8 / 75.0$ & $<$ LOD/256.2 & $<\mathrm{LOD} / 754.5$ & $<\mathrm{LOD} / 15.4$ \\
\hline Trickling filter & Mean \pm SD & $<$ LOD & $<$ LOD & $92.7 \pm 92.1$ & $10.3 \pm 21.2$ & $34.7 \pm 14.8$ & $22.4 \pm 30.9$ & $98.2 \pm 99.4$ & $<$ LOQ \\
\hline 2 effluent & Median & $<$ LOD & $<$ LOD & 62.7 & $<$ LOD & 35.2 & $<$ LOD & 75.3 & $<\mathrm{LOQ}$ \\
\hline Sponge based media & Min/Max & $<\mathrm{LOD} /<\mathrm{LOD}$ & $<\mathrm{LOD} /<\mathrm{LOD}$ & $24.3 / 366.4$ & $<\mathrm{LOD} / 56.8$ & $9.6 / 57.7$ & $<$ LOD/73.2 & $<\mathrm{LOD} / 334.2$ & $<\mathrm{LOD} /<\mathrm{LOQ}$ \\
\hline \multirow{3}{*}{$\begin{array}{l}\text { Polishing ponds } \\
\text { effluent }\end{array}$} & Mean \pm SD & $<\mathrm{LOD}$ & $<\mathrm{LOD}$ & $240.6 \pm 138.5$ & $7.9 \pm 9.3$ & $<$ LOQ & $55.9 \pm 92.0$ & $36.9 \pm 54.0$ & $<\mathrm{LOD}$ \\
\hline & Median & $<$ LOD & $<$ LOD & 271.3 & $<$ LOD & $<$ LOQ & $<$ LOD & $<$ LOD & $<$ LOD \\
\hline & Min/Max & $<\mathrm{LOD} /<\mathrm{LOD}$ & $<\mathrm{LOD} /<\mathrm{LOD}$ & $39.7 / 445.2$ & $<\mathrm{LOD} / 24.2$ & $<$ LOD/15.9 & $<$ LOD/309.2 & $<$ LOD/179.0 & $<\mathrm{LOD} /<\mathrm{LOQ}$ \\
\hline
\end{tabular}

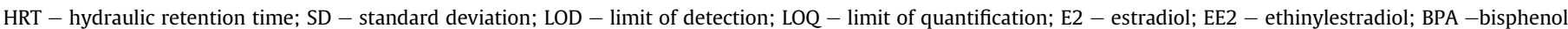
A;SMX - sulfamethoxazole; TRI - trimethoprim; BZF - bezafibrate; DCF - diclofenac; MCZ - miconazole.

The antifungal MCZ was quantified in only a handful of samples; therefore, it was not possible to evaluate its behaviour in the anaerobic reactors.

\subsection{Micropollutant behaviour in the post-treatment units}

Table 5 presents the effluent concentrations of the target micropollutants in the four post-treatment units studied. In addition, Fig. 3 shows the removal/production efficiencies of the studied compounds in these systems. The efficiencies were calculated as described in Fig. 2.

As depicted in Fig. 3, the submerged bed was inefficient in removing NP from the UASB 1 effluent (removal $<20 \%$ ) and removed only half of the BPA effluent after the anaerobic step. It is possible that the occurrence of anaerobic conditions in this unit

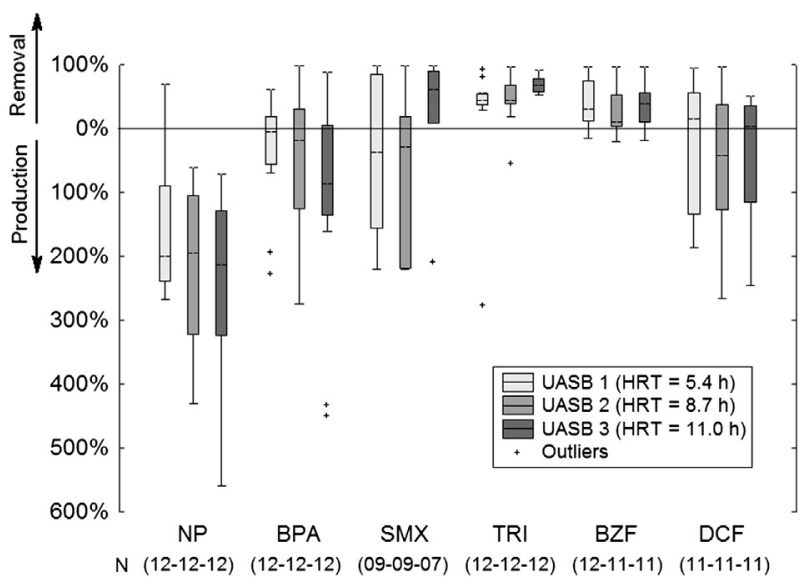

Fig. 2. Efficiency of micropollutant removal/production during treatment in UASB reactors operated at different hydraulic retention times (HRT) over a 3-month monitoring campaign (June 2010-August 2010). Values in parentheses indicate the number of data values $(\mathrm{N})$ (dissolved oxygen in the effluent $=1.3 \pm 0.4 \mathrm{mg} \cdot \mathrm{L}^{-1}$ ) led to zero to partial removal of these EDCs. Alternatively, Fig. 3 also shows that the trickling filters, where the effluent dissolved oxygen was higher $\left(5.6-8.3 \mathrm{mg} \cdot \mathrm{L}^{-1}\right)$, were capable of partially (e.g., BPA) or totally (e.g., NP) removing these EDCs. Jiang et al. (2005) reported a removal of NP and BPA of approximately $60 \%$ and $65 \%$, respectively, in conventional trickling filters treating effluent from primary sedimentation tanks. Therefore, in the present study, the removal of EDCs was similar to the values indicated by Jiang et al. (2005), except for trickling filter 2 (sponge based media), which removed more than $90 \%$ of the NP (significantly different from trickling filter 1 - nonparametric Wilcoxon matched pairs test, $\alpha=5 \%$ ) (Sprent and Smeeton, 2001).

NP has a low aerobic/anaerobic biodegradation rate and a high hydrophobicity (Virkutyte et al., 2010); therefore, its removal normally occurs through sorption mechanisms rather than

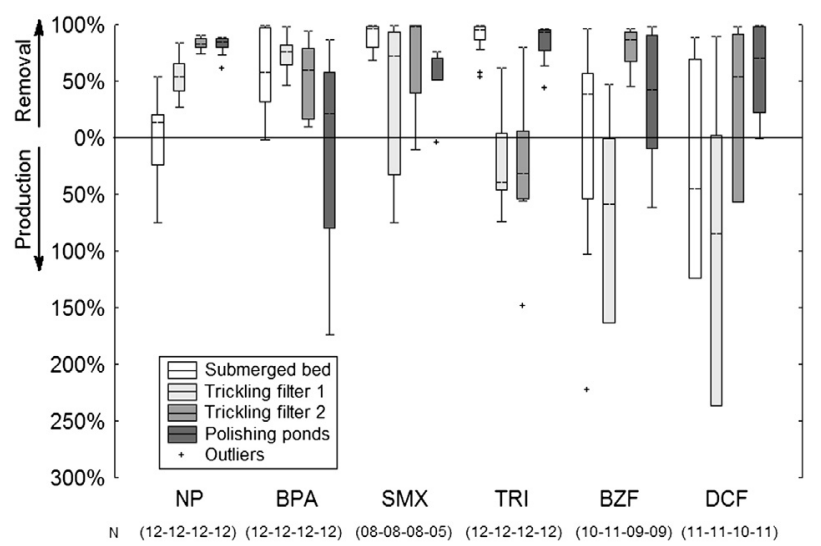

Fig. 3. Efficiency of micropollutant removal/production during treatment in the four post-treatments studied over a 3-month monitoring campaign (June 2010-August 2010). Values in parentheses indicate the number of data values (N). 
biodegradation. The different concentrations of NP in the effluent from the two trickling filters (Table 5) were possibly due to the greater capability of the sponge material to retain the suspended solids (Almeida et al., 2011), which might have contributed to an increase in the contact time between the adsorbed NP and the biomass, thereby enhancing the biodegradation rates. For BPA, this behaviour was not observed, probably because it is less hydrophobic than NP and because BPA can be leached from polyurethane material, such as the sponge used as the filling media in trickling filter 2, thereby contributing to increased BPA concentrations in this effluent.

The polishing ponds exhibited NP removal efficiencies greater than $80 \%$ (Fig. 3), revealing a high performance when compared to the data presented by Ying et al. (2008), who reported an increase of approximately $9 \%$ in the NP concentration in a system comprised of ten ponds in series (anaerobic and facultative). Ahel et al. (1994) assessed the rates of photochemical transformation of NP in natural water by exposing filtered lake water to sunlight. A half-life of 10$15 \mathrm{~h}$ was observed under the surface layer of the natural waters. The photolysis rate in the deeper layers was strongly attenuated and was approximately 1.5 times slower at depths of $20-25 \mathrm{~cm}$ than at the surface (Ahel et al., 1994). Thus, it is possible that the low depth of the polishing ponds in this study (Table 2) contributed to the photolysis of NP, which would not occur in anaerobic and facultative ponds with the same intensity because they are normally deeper.

For the BPA, Froehner et al. (2011) showed that a system comprised of anaerobic ponds in series with facultative and maturative ponds was capable of totally removing this compound from the raw sewage. In addition, Ying et al. (2008) reported a BPA removal efficiency of $60 \%$ in a system comprised of ten ponds in series (anaerobic and facultative), while in the present study, the effectiveness of polishing ponds was quite variable for this compound, with a median removal of less than 25\% (Fig. 3). The HRT applied to the polishing ponds in this study (Table 2) was lower than those usually employed in anaerobic and facultative ponds, which might explain such differences.

As discussed before, BPA can be used as an antioxidant in some plasticisers and as a polymerisation inhibitor in PVC plastic. Therefore, it is possible that some BPA might have leached out from the PVC pipes and the connections that link the three ponds, thereby increasing the BPA effluent concentration.

Fig. 3 also shows that the post-treatment units studied led to a sharp increase in SMX removal from the liquid matrices, notably in the submerged bed and trickling filter 2. The effective removal of the antibiotic SMX in these systems was probably influenced by their great capability of degrading organic matter. According to Joss et al. (2006), SMX has an intermediate aerobic biodegradation constant $\left(\mathrm{K}_{\text {biol }}\right)$ and is highly hydrophilic; therefore, it has a low tendency to adsorb onto solid matrices. The total BOD in the effluents from the submerged bed and trickling filter 2 were $19 \pm 13 \mathrm{mg} \cdot \mathrm{L}^{-1}$ and $21 \pm 11 \mathrm{mg} \cdot \mathrm{L}^{-1}$, respectively, whereas for trickling filter 1 and the polishing ponds, these values were somewhat higher at $52 \pm 10 \mathrm{mg} \cdot \mathrm{L}^{-1}$ and $45 \pm 58 \mathrm{mg} \cdot \mathrm{L}^{-1}$, respectively. The BOD conversion was higher in the submerged bed and trickling filter 2 probably because of the higher biomass accumulation; it is likely that SMX co-metabolism was enhanced in these units. The removal efficiency of SMX in the polishing ponds could not be confirmed because the previous anaerobic unit ensured almost total removal of the antibiotic (see Table 5), leaving only five data available for calculation. Nevertheless, a reduction in the variation range of SMX concentrations was observed in the polishing pond effluents (Table 5).

As depicted in Fig. 3, the submerged bed and polishing pond units performed well for removing TRI from the anaerobic effluents, whereas the trickling filters were rather ineffective in doing so. An increase in the TRI concentration in the effluent from biological reactors is usually attributed to the hydrolysis of conjugates of this antibiotic that are normally present in raw sewage (Plósz et al., 2010). The longer HRT applied in the submerged bed and polishing ponds (see Table 2) might have been crucial for the largest TRI removal observed in these units. Because TRI is also a highly hydrophilic compound and is less biodegradable than SMX (Li and Zhang, 2010), it seems that TRI can only be biologically removed when high contact times (HRT $>29 \mathrm{~h}$ ) are applied to the biological reactors.

As far as the other pharmaceuticals (BZF and DCF) are concerned, Fig. 3 shows that trickling filter 2 and the polishing ponds performed better at removing BZF and DCF from the anaerobic effluents, varying from intermediate removal efficiencies for BZF and DCF in the polishing ponds and trickling filter 2, respectively, to a good removal of BZF and DCF in trickling filter 2 and the polishing ponds, respectively. The other post-treatment units (submerged bed and trickling filter 1 ) led to a poor removal or even production of these pharmaceuticals. An increase in the concentration of DCF was also observed by Kasprzyk-Hordern et al. (2009) in trickling filters treating effluent from primary sedimentation tanks, and the authors attributed this to the hydrolysis of DCF conjugates. As observed for NP and SMX, there was a substantial effect from using different types of bed material on the removal efficiency or production of BZF and DCF in the trickling filters (statistically confirmed - nonparametric Wilcoxon matched pairs test, $\alpha=5 \%$ ) (Sprent and Smeeton, 2001). This implies that the type of packing material and the amount of biomass retention in the trickling filters have a great influence on the behaviour of micropollutants, which have distinct properties (e.g., hydrophobic x hydrophilic).

BZF has a dissociation constant (pKa) and an octanol-water partition coefficient $\left(\log K_{o w}\right.$ ) value of approximately 3.3 and 4.32 , respectively. For DCF, these values are approximately 4.2 and 4.51 , respectively. Therefore, although such compounds have a high tendency to sorb onto grease materials (high log $\mathrm{K}_{\mathrm{ow}}$ ), they are deprotonated (have negative charge) in the operational $\mathrm{pH}$ of the treatment systems. This means that these compounds would tend to be sorbed onto hydrophobic surfaces; however, they could also be repelled by negatively charged solids, such as biomass (Suárez et al., 2008). These opposing factors might have been decisive in the observed removal efficiencies of BZF and DCF in the two trickling filters studied. Furthermore, the $\mathrm{K}_{\mathrm{biol}}$ value of DCF is smaller than $0.1 \mathrm{~L} \cdot \mathrm{g}_{S S}^{-1} \cdot \mathrm{d}^{-1}$, and in the case of BZF, it ranges from 4 to $7 \mathrm{~L} \cdot \mathrm{gSS}_{\mathrm{SS}}^{-1} \cdot \mathrm{d}^{-1}$ (Joss et al., 2006), indicating low biodegradability of these compounds.

With respect to the polishing ponds, it seems that the large surface area exposed to sunlight, together with the higher HRT, was decisive for DCF removal from the anaerobic effluent. Buser et al. (1998) reported a removal efficiency of $90 \%$ for DCF in a natural lake, and a large part of its removal was attributed to photolysis. This study involved laboratory tests and demonstrated that biodegradation was negligible and that the half-life for DCF photolysis was only $1 \mathrm{~h}$. However, their experiment was carried out in an aquatic environment (lake) with far less turbidity when compared to that normally measured in the polishing ponds studied here.

\subsection{Micropollutant removal in simplified WWTPS}

Fig. 4 shows the global removal/production efficiencies of the studied compounds in the simplified systems, consisting of UASB reactors followed by distinct post-treatment units (submerged bed - SB, trickling filters - TF, and polishing ponds - PP). The efficiencies were calculated as explained previously. 


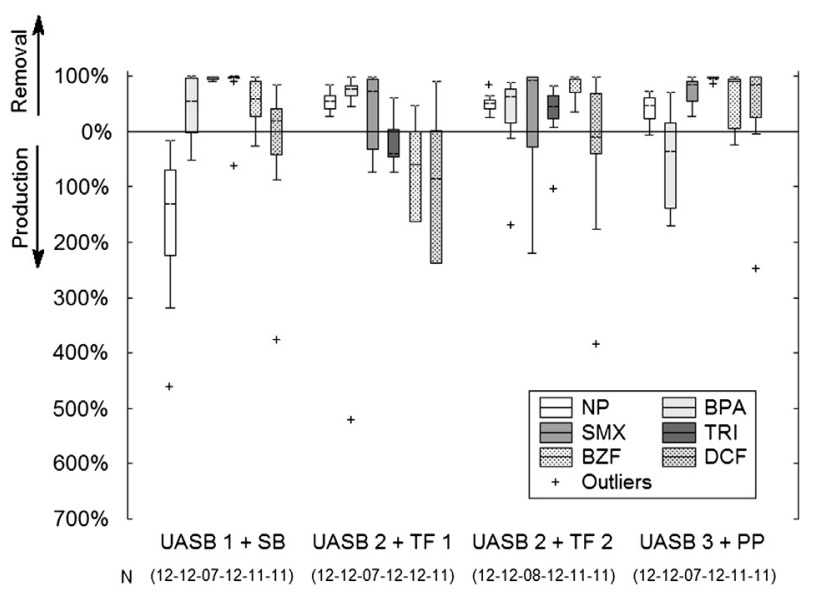

Fig. 4. Efficiency of micropollutant removal/production for the overall treatment systems (UASB reactors + post-treatments) over a 3-month monitoring campaign (June 2010-August 2010). Values in parentheses indicate the number of data values (N). Note: SB - submerged bed; TF - trickling filters; PP - polishing ponds.

As depicted in Fig. 4, the UASB + polishing ponds system showed the best removal efficiencies for the greatest number of micropollutants. Of the six evaluated compounds, four were effectively removed, and the EDCs (NP and BPA) were those that were not effectively removed from the sewage. The UASB + submerged bed system showed high removal efficiencies for two (SMX and TRI) out of the six micropollutants studied, with partial removal for BPA and DCF, and poor removal for NP and DCF.

Likewise, the compact UASB + trickling filter 2 system (filled with sponge based media) exhibited high removal efficiencies for two (SMX and BZF) of the micropollutants studied, while the others were only partially removed or even produced during treatment, as was the case for DCF. The UASB + trickling filter 1 system (filled with plastic based media) proved to be the least effective in removing the studied micropollutants from the sewage. For this system, none of the six monitored compounds were effectively removed. Three compounds were only partially removed, while the other three seemed to be produced (NP, BZF, and DCF) by the treatment, probably because hydrolysis or partial degradation of conjugates and precursors prevailed over their mineralisation.

In order to compare the pharmaceutical and endocrine removal efficiencies observed in the simplified treatment systems studied here with those shown by the activated sludge (AS) systems, data gathered from different studies and research groups (Carballa et al., 2004; Clara et al., 2005a, 2005b; Joss et al., 2005; Vieno et al., 2005; Batt et al., 2006; Bernhard et al., 2006; Lishman et al., 2006; Nakada et al., 2006; Göbel et al., 2007; Radjenovic et al., 2007; Tan et al., 2007; Gulkowska et al., 2008; Pothitou and Voutsa, 2008; Ying et al., 2008; Janex-Habib et al., 2009; Kasprzyk-Hordern et al., 2009; Radjenovic et al., 2009; Choubert et al., 2011; Jelic et al., 2011; McAdam et al., 2011; Pedrouzo et al., 2011; Zhang et al., 2011) was compiled and presented in Fig. 5. In order to reduce the effect of distinct operational conditions employed, the data were organized into two distinct groups, according to the value of solid retention time (SRT) employed in the AS systems reviewed. Systems with SRT $\leq 10 \mathrm{~d}$ were thereby considered 'conventional activated sludge (CAS)' whereas those with SRT $>10 \mathrm{~d}$ were classified as 'extended aeration activated sludge (EAAS)' systems, thus following what is recommended by AS specialists (Von Sperling, 2002).

When Fig. 4 is compared with the data compiled from the literature (Fig. 5), it can be noticed that all simplified UASB/posttreatment systems studied here had a higher median removal efficiency of SMX when compared to AS, which normally exhibit poor

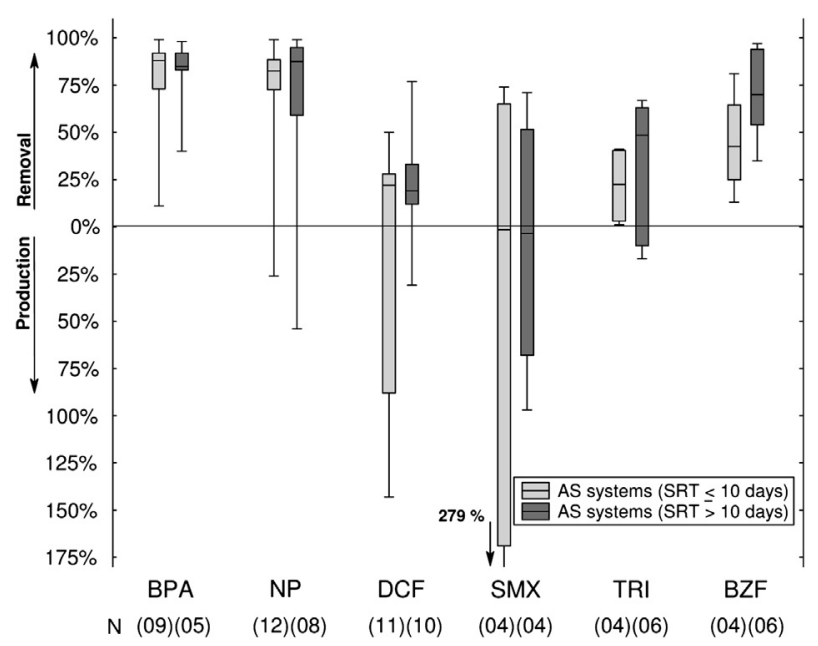

Fig. 5. Removal efficiencies of selected pharmaceuticals and endocrine disrupting compounds by activated sludge systems operated at distinct solid retention times.

performance in removing such antibiotic, even when higher SRT are employed. For the other antibiotic studied here (TRI), it was noticed that the systems UASB-PP and UASB-SB led to higher removal efficiencies when compared to AS systems ( 25\% for CAS and 50\% for EAAS), whereas for the system UASB-TF2 the removal efficiency was comparable with that of CAS. Since TRI is recalcitrant and hydrophilic, a higher HRT, such as observed in the UASB-PP and UASBSB systems, seems to be a parameter more important than the SRT to predict its removal in treatment systems.

For the anti-inflammatory DCF, which is also poorly removed by AS systems, only the UASB-PP system exhibited a higher removal efficiency. In the case of such hydrophilic and recalcitrant pharmaceutical, the other natural system studied (UASB-SB) had a removal performance comparable with EAAS system, whereas the UASB-TF led to low and highly variable removal efficiencies, probably due to the low HRT employed.

Regarding the antilipemic BZF, Fig. 5 shows that AS systems exhibited low $(\sim 45 \%)$ to intermediate $(\sim 75 \%)$ median removal efficiencies, depending on the SRT employed, and such values are lower or comparable with those observed in the UASB-PP, UASB-SB and UASB-TF2 systems, which have higher HRT values (except UASBTF2) than those employed in the AS systems reviewed. This also implies that for BZF, which is a hydrophilic acidic compound, the HRT might be a better parameter to predict its removal than the SRT.

As far as the hydrophobic phenol compounds (BPA and NP) are concerned, it can be seen that only the UASB-TF systems resulted in intermediate removal efficiencies $(\sim 50-75 \%)$ which are lower than those observed in AS systems ( $\sim 8590 \%)$. This might be due to lower sludge accumulation, especially in trickling filter 1 , when compared to AS systems, since it is well known that NP and BPA are preferably removed by adsorption onto biomass.

Overall, the results presented in Figs. 4 and 5 show that the simplified treatment systems studied here, except exhibited a better or comparable performance in the removal of than AS systems, in the removal of most micro-pollutants investigated. The system UASB- trickling filter 1 exhibited the worst overall performance whereas the system UASB-TF2 led to removal efficiencies which were higher than AS system for all monitored contaminants.

\section{Conclusions}

- This work confirms that UASB reactors were not appropriate for an efficient removal of NP, BPA, DCF, BZF, SMX, and TRI from 
sewage and showed that the HRT is an important parameter controlling the removal of the hydrophilic and less biodegradable contaminants, such as SMX and TRI;

- The post-treatment units substantially increased the removal of most of the target micropollutants present in the anaerobic effluents. The results show that there was a greater removal of the micropollutants monitored in natural systems, such as the submerged bed and polishing ponds, probably because of the higher residence times employed in these treatment units;

- This work also showed that more compact post-treatment systems, such as trickling filters that were operated with a low HRT $(<2 \mathrm{~h}$ ), tended to be less efficient at removing pharmaceuticals and EDC, especially when using packing material that does not lead to high solids retention;

- Simplified sewage treatment systems, comprised of UASB reactors followed by natural (polishing ponds, submerged beds) or compact (trickling filter packed with sponge-based material) post-treatment units, can remove hydrophilic and hydrophobic pharmaceuticals and endocrine disrupting compounds as efficiently as activated sludge systems.

\section{Acknowledgements}

The authors thank the following institutions for the support provided:

- Conselho Nacional de Desenvolvimento Científico e Tecnológico - CNPq;

- Coordenação de Aperfeiçoamento de Pessoal de Nível Superior - CAPES;

- Fundação de Amparo à Pesquisa de Minas Gerais - FAPEMIG;

- Pro-Reitoria de Pesquisa da Universidade Federal de Minas Gerais - PRPq/UFMG;

The authors are also grateful to the following people who helped in various ways in this work: Professor Marcos von Sperling, Professor Maurício Coutrim, Paulo Almeida, Bruna Borba, and Mark Le Petit.

\section{References}

Ahel, M., Scully, F.E., Hoigné Jr., J., Giger, W., 1994. Photochemical degradation of nonylphenol and nonylphenol polyethoxylates in natural waters. Chemosphere 28 (7), 1361-1368.

Aherne, G.W., English, J., Marks, V., 1985. The role of immunoassay in the analysis of microcontaminants in water samples. Ecotoxicology and Environment Safety 9, 79-83.

Almeida, P.G.S., Marcus, A.K., Rittmann, B.E., Chernicharo, C.A.L., 2011. Performance of plastic- and sponge-based trickling filter treating effluents from an UASB reactor. In: X Latin American Workshop and Symposium on Anaerobic Digestion (DAAL). IWA, Ouro Preto, Brazil.

Batt, A.L., Kim, S., Aga, D.S., 2006. Enhanced biodegradation of iopromide and trimethoprim in nitrifying activated sludge. Environmental Science \& Technology 40, 17367-17373.

Bernhard, M., Müller, J., Thomas, P.K., 2006. Biodegradation of persistent polar pollutants in wastewater: comparison of an optimized lab-scale membrane bioreactor and activated sludge treatment. Water Research 40, 3419-3428.

Buser, H., Poiger, T., Müller, M.D., 1998. Pharmaceutical drug diclofenac in surface waters: rapid photodegradation in a Lake. Environmental Science \& Technology 32 (22), 3449-3456.

Carballa, M., Omil, F., Lema, J.M., Llompart, M., García-Jares, C., Rodríguez, I. Gómez, M., Ternes, T., 2004. Behavior of pharmaceuticals, cosmetics and hormones in a sewage treatment plant. Water Research 38, 2918-2926.

Carlsen, E., Giwercman, A., Keiding, N., Skakkebaek, N.E., 1992. Evidence for decreasing quality of semen during past 50 years. British Medical Journal 305 (6854), 609-613.

Chernicharo, C.A.L., 2006. Post-treatment options for the anaerobic treatment of domestic wastewater. Reviews in Environmental Science and Biotechnology 5, 73-92.

Choubert, J.M., Ruel, S.M., Esperanza, M., Budzinski, H., Miège, C., Lagarrigue, C., Coquery, M., 2011. Limiting the emissions of micro-pollutants: what efficiency can we expect from wastewater treatment plants? Water Science \& Technology $63,57-65$.

Clara, M., Strenn, B., Gans, O., Martinez, E., Kreuzinger, N., Kroiss, H., 2005a. Removal of selected pharmaceuticals, fragrances and endocrine disrupting compounds in a membrane bioreactor and conventional wastewater treatment plants. Water Research 39, 4797-4807.

Clara, M., Kreuzinger, N., Strenn, B., Gans, O., Kroiss, H., 2005b. The solids retention time - a suitable design parameter to evaluate the capacity of wastewater treatment plants to remove micropollutants. Water Research 39, 97-106.

Froehner, S., Piccioni, W., Machado, K.S., Aisse, M.M., 2011. Removal capacity of caffeine, hormones, and bisphenol by aerobic and anaerobic sewage treatment. Water, Air \& Soil Pollution 216, 463-471.

Göbel, A., McArdell, C.S., Joss, A., Siegrist, H., Giger, W., 2007. Fate of sulfonamides, macrolides, and trimethoprim in different wastewater treatment technologies. Science of the Total Environment 372, 361-371.

Guenther, K., Kleist, E., Thiele, B., 2006. Estrogen-active nonylphenols from an isomer-specific viewpoint: a systematic numbering system and future trends. Analytical and Bioanalytical Chemistry 384, 542-546.

Guillette Jr., L.J., Pickford, D.B., Crain, D.A., Rooney, A.A., Percival, H.F., 1996 Reduction in penis size and plasma testosterone concentrations in juvenile alligators living in a contaminated environment. General and Comparative Endocrinology 101 (1), 32-42.

Gulkowska, A., Leung, H.W., So, M.K., Taniyasu, S., Yamashita, N., Yeung, L.W.Y. Richardson, B.J., Lei, A.P., Giesy, J.P., Lam, P.K.S., 2008. Removal of antibiotics from wastewater by sewage treatment facilities in Hong Kong and Shenzhen, China. Water Research 42, 395-403.

Halling-Sørensen, B., Nielsen, S.N., Lanzky, P.F., Ingerslev, F., Lutzheft, H.C.H. Jørgensen, S.E., 1998. Occurrence, fate and effects of pharmaceutical substances in the environment - a review. Chemosphere 36 (2), 357-393.

Hignite, C., Azarnoff, D.L., 1977. Drugs and drug metabolites as environmental contaminants: chlorophenoxyisobutyrate and salicylic acid in sewage water effluent. Life Sciences 20 (2), 337-341.

Janex-Habib, M., Huyard, A., Esperanza, M., Bruchet, A., 2009. Reduction of endocrine disruptor emissions in the environment: the benefit of wastewater treatment. Water Research 43, 1565-1576.

Jelic, A., Gros, M., Ginebreda, A., Cespedes-Sánchez, R., Ventura, F., Petrovic, M., Barcelo, D., 2011. Occurrence, partition and removal of pharmaceuticals in sewage water and sludge during wastewater treatment. Water Research 45, 1165-1176.

Jiang, J.Q., Yin, Q., Zhou, J.L., Pearce, P., 2005. Occurrence and treatment trials of endocrine disrupting chemicals (EDCs) in wastewaters. Chemosphere 61,544-550.

Jobling, S., Nolan, M., Tyler, C.R., Brighty, G., Sumpter, J.P., 1998. Widespread sexual disruption in wild fish. Environmental Science \& Technology 32, 2498-2506.

Joss, A., Keller, E., Alder, A.C., Göbel, A., Mcardell, C.S., Ternes, T., Siegrist, H., 2005 Removal of pharmaceuticals and fragrances in biological wastewater treatment. Water Research 39, 3139-3152.

Joss, A., Zabczynski, S., Göbel, A., Hoffmann, B., Löffler, D., McArdell, C.S., Ternes, T.A., Thomsen, A., Siegrist, H., 2006. Biological degradation of pharmaceuticals in municipal wastewater treatment: proposing a classification scheme. Water Research 40, 1686-1696.

Kashiwada, S., Ishikawa, H., Miyamoto, N., Ohnishi, Y., Magara, Y., 2002. Fish test for endocrine-disruption and estimation of water quality of Japanese rivers. Water Research 36, 2161-2166.

Kasprzyk-Hordern, B., Dinsdale, R.M., Guwy, A.J., 2009. The removal of pharmaceuticals, personal care products, endocrine disruptors and illicit drugs during wastewater treatment and its impact on the quality of receiving waters. Water Research 43, 363-380.

Kim, S., Aga, D.S., 2007. Potential ecological and human health impacts of antibiotics and antibiotic-resistant bacteria from wastewater treatment plants. Journal of Toxicology and Environmental Health - Part B 10 (8), 559-573.

Kim, S.D., Cho, J., Kim, I.S., Vanderford, B.J., Snyder, S.A., 2007. Occurrence and removal of pharmaceuticals and endocrine disruptors in South Korean surface, drinking, and waste waters. Water Research 41, 1013-1021.

Kujawa-Roeleveld, K., Schuman, E., Grotenhuis, T., Kragić, D., Mels, A., Zeeman, G., 2008. Biodegradability of human pharmaceutically active compounds (PhAC) in biological systems treating source separated wastewater streams. In: Proceeding of the IWA International Conference Sanitation Challenge, Wageningen, the Netherlands.

Kümmerer, K., 2010. Pharmaceuticals in the Environment. The Annual Review of Environment and Resources 35, 57-75.

Li, B., Zhang, T., 2010. Biodegradation and adsorption of antibiotics in the activated sludge process. Environmental Science \& Technology 44, 3468-3473.

Lishman, L., Smyth, S.A., Sarafin, K., Kleywegt, S., Toito, J., Peart, T., Lee, B., Servos, M., Beland, M., Seto, P., 2006. Occurrence and reductions of pharmaceuticals and personal care products and estrogens by municipal wastewater treatment plants in Ontario, Canada. Science of the Total Environment 367, 544-558.

McAdam, E.J., Bagnall, J.P., Soares, A., Koh, Y.K.K., Chiu, T.Y., Scrimshaw, M.D., Lester, J.N., Cartmell, E., 2011. Fate of alkylphenolic compounds during activated sludge treatment: impact of loading and organic composition. Environmental Science \& Technology 45, 248-254.

Miège, C., Choubert, J.M., Ribeiro, L., Eusèbe, M., Coquery, M., 2008. Removal efficiency of pharmaceuticals and personal care products with varying wastewater treatment processes and operating conditions - conception of a database and first results. Water Science \& Technology 57 (1), 49-56. 
Moreira, D.S., Aquino, S.F., Afonso, R.J.C.F., Santos, E.P.P.C., Pádua, V.L., 2009. Occurrence of endocrine disrupting compounds in water sources of Belo Horizonte Metropolitan Area, Brazil. Environmental Technology 30 (10), 1041-1049.

Moreira, M.A., Aquino, S.F., Coutrim, M.X., Silva, J.C.C., Afonso, R.J.C.F., 2011. Determination of endocrine-disrupting compounds in waters from Rio das Velhas, Brazil, by liquid chromatography/high resolution mass spectrometry (ESI-LC-ITTOF/MS). Environmental Technology 32 (11-12), 1409-1417.

Nakada, N., Tanishima, T., Shinohara, H., Kiri, K., Takada, H., 2006. Pharmaceutical chemicals and endocrine disrupters in municipal wastewater in Tokyo and their removal during activated sludge treatment. Water Research 40, 3297-3303.

Pedrouzo, M., Borrull, F., Pocurull, E., Marcé, R.M., 2011. Presence of pharmaceuticals and hormones in waters from sewage treatment plants. Water, Air, \& Soil Pollution 217 (1-4), 267-281.

Plósz, B.G., Leknes, H., Liltved, H., Thomas, K.V., 2010. Diurnal variations in the occurrence and the fate of hormones and antibiotics in activated sludge wastewater treatment in Oslo, Norway. Science of the Total Environment 408 (8), 1915-1924.

Pothitou, P., Voutsa, D., 2008. Endocrine disrupting compounds in municipal and industrial wastewater treatment plants in Northern Greece. Chemosphere 73, 1716-1723.

Queiroz, F.B., 2011. Desenvolvimento e validação de metodologia para determinação de fármacos e perturbadores endócrinos em amostras de esgoto utilizando extração em fase sólida e cromatografia líquida acoplada à espectrometria de massas. M.Sc. Thesis. Federal University of Ouro Preto, p. 114 (in Portuguese)

Radjenovic, J., Petrovic, M., Barceló, D., 2007. Analysis of pharmaceuticals in wastewater and removal using a membrane bioreactor. Analytical and Bioanalytical Chemistry 387, 1365-1377.

Radjenovic, J., Petrovic, M., Barceló, D., 2009. Fate and distribution of pharmaceuticals in wastewater and sewage sludge of the conventional activated sludge (CAS) and advanced membrane bioreactor (MBR) treatment. Water Research 43, 831-841.

Sipma, J., Osuna, B., Collado, N., Monclús, H., Ferrero, G., Comas, J., RodriguezRoda, I., 2009. Comparison of removal of pharmaceuticals in MBR and activated sludge systems. Desalination 250 (2), 653-659.

Sodré, F.F., Locatelli, M.A.F., Jardim, W.F., 2010. Occurrence of emerging contaminants in Brazilian drinking waters: a sewage-to-tap issue. Water, Air, \& Soil Pollution 206, 57-67.

Sprent, P., Smeeton, N.C., 2001. Applied Nonparametric Statistical Methods. Chapman e Hall/CRC, New York.
Stumpf, M., Ternes, T.A., Wilken, R., Rodrigues, S.V., Baumann, W., 1999. Polar drug residues in sewage and natural waters in the state of Rio de Janeiro, Brazil. The Science of the Total Environment 255, 135-141.

Suárez, S., Carballa, M., Omil, F., Lema, J.M., 2008. How are pharmaceutical and personal care products (PPCPs) removed from urban wastewaters? Reviews in Environmental Science and Biotechnology 7,125-138.

Tan, B.L.L., Hawker, D.W., Müller, J.F., Leusch, F.D.L., Tremblay, L.A., Chapman, H.F. 2007. Comprehensive study of endocrine disrupting compounds using grab and passive sampling at selected wastewater treatment plants in South East Queensland, Australia. Environment International 33, 654-669.

Ternes, T.A., 1998. Occurrence of drugs in German sewage treatment plants and rivers. Water Research 32 (11), 3245-3260.

Ternes, T.A. Stumpf, M., Mueller, J., Haberer, K., Wilken, R.D., Servos, M., 1999. Behavior and occurrence of estrogens in municipal sewage treatment plants 1: investigations in German, Canada and Brazil. Science of the Total Environment 225, 80-90.

USEPA, 2007. Method 1694: Pharmaceuticals and Personal Care Products in Water Soil, Sediment, and Biosolids by HPLC/MS/MS. U.S. Environmental Protection Agency, Washington D.C., U.S.A.

USEPA, 2009. Occurrence of Contaminants of Emerging Concern in Wastewater From Nine Publicly Owned Treatment Works. U. S. Environmental Protection Agency, Washington D.C., U.S.A

Vandenberg, L.N., Hauser, R., Marcus, M., Olea, N., Welshons, W.V., 2007. Human exposure to bisphenol A (BPA). Reproductive Toxicology 24, 139-177.

Vieno, N.M., Tuhkanen, T., Kronberg, L., 2005. Seasonal variation in the occurrence of pharmaceuticals in effluents from a sewage treatment plant and in the recipient water. Environmental Science \& Technology 39, 8220-8226.

Virkutyte, J., Varma, R.S., Jegatheesan, V. (Eds.), 2010. Treatment of Micropollutants in Water and Wastewater. IWA Publishing, London, UK.

WHO, 2002. In: Damstra, T., Barlow, S., Bergman, A., Kavlock, R., Van Der Kraak, G. (Eds.), International Programme on Chemical Safety - Global Assessment of the State-of-the-science of Endocrine Disruptors. World Health Organization.

Ying, G., Kookana, R.S., Kumar, R., 2008. Fate of estrogens and xenoestrogens in four sewage treatment plants with different technologies. Environmental Toxicology and Chemistry 27 (1), 87-94.

Zhang, Z., Feng, Y., Gao, P., Wang, C., Ren, N., 2011. Occurrence and removal efficiencies of eight EDCs and estrogenicity in a STP. Journal of Environmental Monitoring 13 (5), 1366-1373. 